Urban Water Systems \& Floods III 155

\title{
USING AN ECOSYSTEM SERVICES LENS TO EXPLORE A BROADER FUNDING BASE FOR LANEWAYS
}

\author{
JESSICA LAMOND, MARK EVERARD \& GLYN EVERETT \\ University of the West of England, UK
}

\begin{abstract}
Greening small urban street spaces such as alleys and laneways is increasingly popular with city authorities. Motivation for starting these projects varies and this may hold implications in terms of the responsible function and department overseeing planning and implementation. Knock-on effects of such decisions may also include the level and breadth of stakeholder engagement and consultation in the process, the visions created and the eventual benefits realised. This research explored the potential to widen funding sources for a laneways project in Melbourne, Australia, including crowd funding. An ecosystem services framework was used to extensively consider potential benefits from a project before and during the design phase. The findings indicate that such an approach can be very useful in order to: widen participation; tailor design to optimise benefits; bring funding from special interest groups; and increase visibility and potential for improved feedback benefits such as green tourism and property values.
\end{abstract}

Keywords: laneways, Blue-Green Infrastructure, Green Infrastructure, ecosystems services.

\section{INTRODUCTION}

Greening small urban pedestrian street spaces such as alleys or laneways is increasingly popular with city authorities [1], [2]. The spaces have different names but a common feature is that they provide "access to the back of properties which have a complementary street as their primary and front access" [3]. The driving motivation for starting these projects varies, however they may often include a stormwater management element within the design. Newell et al. [4] concluded that the schemes they analysed were mostly narrowly focussing on stormwater, whereas Lindt [1] recognised some schemes in the US had an economic or a social focus. Meanwhile, in Australia a process called "activation" of laneways has been part of an urban revitalisation strategy in large and small cities [2] but of the six small cities studied in Queensland, none had considered greening as a regeneration strategy. Nevertheless, the diversity urban "green infrastructure" (GI) solutions provide opportunities to optimise a wide range of ecosystem services of cumulatively significant benefit to urban residents and users and the general "liveability" of the city [5].

Multiple benefits of retrofit Blue-Green Infrastructure (BGI) such as green roofs in cities have been considered to benefit a wide range of stakeholders [6], [7] directly and indirectly beyond those generally considered and therefore consulted. However, in designing projects, a full assessment of actual or potential benefits is not generally addressed, resulting in many potential benefits and community interests being overlooked, undervalued and not realised during design and implementation [8].

Research that can inform the design of schemes towards optimising benefits is limited but indicates that perceptions and preferences of communities are important, they vary and they impact on acceptability and sustainability. While there is some research that examines the suitability of different plantings in a hydrological sense [9], very little research investigates which plants and functions communities prefer [10]. Research and best practice call for the contextualisation of benefits and the examination of specific needs and limitations locally. Consultation may be seen as onerous and a cost and delay to projects, but an alternative view is that it represents a method to bolster wider public support and also bring additional funding 
opportunities to the table by optimising interlinked benefits and tailoring design to engage and transparently benefit wider interest groups. Partnerships between local communities, interest groups and authorities naturally ensue, but defining the scope of consultees requires some prior understanding of potential beneficiaries.

This decentralisation of engagement with and funding of local natural infrastructure, comprising natural processes protected, restored or emulated to add value to engineered infrastructure is also part of a wider political discourse and policy focus. The UK government used the term "Big Government" to "Big Society" to describe the process of shifting the balance of power from central control to citizens, communities and local government, devolving powers to work together and solve localised perceived problems [11].

Historic development of Melbourne City in the Victorian era was around a grid of city streets, and between them a less predictable weave of laneways. These laneways are mostly pedestrian, many covered, and have become a significant draw for both tourists and local people due to a proliferation of multicultural food and drink, fashion and art, and other "boutique" businesses distinctive to Melbourne [12]. Between 2015-2017 the Melbourne Laneways project sought to explore the potential to "green" laneways in order to alleviate surface water and urban heat islands [13]. The research reported here was carried out over the same period to provide evidence to enable future stages of the programme. The aim of the research was to consider the range of interconnected benefits potentially arising from the greening of Melbourne's laneways in order to: map stakeholders likely to receive those benefits; to identify alternative and novel funding partners; and to support the ambition to gain some support for crowd funding future laneway greening projects.

\section{METHOD}

The approach taken is a deductive ecosystem services analysis to broaden the thinking about the stakeholders and potential funding routes for the "greening" of Melbourne's laneways. The research also drew upon already existing concepts of benefits provided by Melbourne City Council (see Table 1) [14]. The potential benefits from Laneways were then brainstormed by a team of researchers from built and natural environment, in collaboration with local experts, using the ecosystem framework to learn about potential beneficial outcomes resulting from greening and to map these to beneficiaries across a range of scales.

\subsection{Approaching the benefits of greening from the perspectives of ecosystem services}

The clustering of potential benefits under the three principal sustainable development vectors of "environmental", "economic" and "social" is helpful. However, a commonly encountered problem - frequently encountered in practical implementation of purported systems approaches - is that inherent interdependencies between these three parameters tend to be overlooked. For example, a tree planted in a laneway may confer benefits: Environmentally through providing some habitat for wildlife, cooling and cleansing the air; and slowing down flood generation; Socially, by the fact that "greener" views tend to reduce personal stress (as outlined below) as well as less polluted air having direct health benefits; and Economically, A more pleasant vista can significantly enhance local real estate values, the cleaner air can have implications for health costs, and buffering of flood risk can avert the costs of defence or damage.

It is also important to ensure that potential disbenefits are considered. For this reason, we use a framework that takes account of these systemic interdependencies as the basis for a broader assessment of linked benefits and potential disbenefits arising from different approaches to greening the laneways. As many of these potential benefits and disbenefits are 
vectored to and between people via ecosystem functions, we have selected the ecosystem services framework for this purpose.

Ecosystem services are defined by the UN Millennium Ecosystem Assessment (MA) as "...the benefits people obtain from ecosystems", thus they are inherently anthropocentric. However, many of the diverse services are not immediately utilitarian, some rely on valueladen, aesthetic and cultural benefits while others are related to quality of living conditions. They also encompass the integrity and resilience of ecosystems and their continued capacity to function and produce services. Specifically, we use the classification of ecosystem services developed to by the MA [15]. The MA classification of ecosystem services integrated a wide range of pre-existing ecosystem service classifications, many addressing specific habitat types and bioregional perspectives. Importantly, the MA classification explicitly spans diverse value systems across its four qualitatively different categories (see Table 2).

Table 1: Existing thinking about the Benefits of Laneway Greening published by Melbourne City [14].

The challenge of a changing climate is providing opportunities to change the way we see and create our cities. The introduction of green spaces in built up areas has many real benefits and can help cities adapt to extreme weather events, increasing urban density, population increases, reducing excess urban warming and enhancing community health and wellbeing.

Trees, vines and plants in Melbourne's laneways can provide multiple benefits such as:

\section{Environmental}

- diverting storm water run-off from laneways into the soil

- $\quad$ filtering dust and pollution from the air

- improving biodiversity levels in the central city

- the provision of habitat for wildlife

- reducing noise levels in the city

- insulating buildings from heat and cold, reducing energy expenditure and carbon emissions

- $\quad$ reducing the Urban Heat Island (UHI) effect through shading and cooling.

Economic

- $\quad$ insulating the building in winter and summer, reducing heating and cooling costs

- extending the life expectancy of impervious surfaces

- increasing surrounding property values

- $\quad$ provision of useable green outdoor space for businesses in laneways e.g. bars, cafes and restaurants.

\section{Social}

- $\quad$ provision of more green public open spaces in the central city

- reinvigorating laneways from waste areas to useable public spaces

- provision of more pleasant walkways and thoroughfares, encouraging people to walk and spend time outdoors

- reducing vandalism and antisocial behaviour

- bringing nature into the city which has positive effects in reducing depression and illness

- $\quad$ further promoting the City of Melbourne as a sustainable, resilient, livable city. 
Table 2: Ecosystem services category adapted from World Resources Institute [15].

- Provisioning services: food, fresh water, biochemicals and other substances and energy that can be extracted from nature;

- Regulatory services: natural processes that regulate, for example, flows and quality of air and water, erosion, diseases and climate;

- Cultural services: non-material benefits derived from nature such as spiritual enrichment, tourism and recreation opportunities, and education and research; and

- Supporting services: processes such as soil formation, photosynthesis and the cycling of nutrients and water that maintain ecosystem functioning, resilience and capacity to keep producing other more directly utilised services

All ecosystem services enhance different aspects of human wellbeing [15]. However, the supporting services are, as their name suggests, doing so indirectly through enhanced ecosystem integrity, health and by boosting the systems production of provisioning, cultural and regulatory services. Mirroring this a key element of human wellbeing, "Freedom of choice and action" depends on satisfaction of other more basic biophysical and social needs supported by ecosystem services.

This framework recognises the interconnectivity of ecosystems, the services they provide and the benefits derived. It provides a deductive tool to translate choices in technologies, and management or use of habitat, landscapes and urban spaces into changes in ecosystem vitality and functioning. Ultimately such choices can be observed impacting on an intimately connected network of social and economic benefits and disbenefits.

Several models of the ecosystem service framework have been proposed. Early precursors included habitat and location specific classifications such as Dugan [16] wetland model and the SWAMP model by Everard et al. [17], all ultimately informing the $2005 \mathrm{MS}$ classification. Development of subsequent models include those of The Economics of Ecosystems and Biodiversity (TEEB) ecosystem services framework [18]; the Common International Classification of Ecosystem Services (CICES) [19] developed by the European Environment Agency (EEA); and the economic model of the UK National Ecosystem Assessment (UK NEA) [20] that seeks to monetise services as far as possible. Many of these subsequent reclassifications omit supporting services to avert double-counting of their contributions to other more directly exploited services. However, since valuation was not a feature of this study, inclusion of the fundamental roles supporting services play in productive ecosystems are vital for informing sustainable development and management strategies.

Our use of the MA classification relates to the recognition of all services, marketed and monetisable as well as non-market, as it is important to account for the full range of benefits and potential disbenefits in decision-making. Otherwise, established markets will continue substantially to distort the allocation of resources and hence the viability of productive systems. In an urban setting, financial returns from markets may today reward maximisation of built assets per unit area, yet costs in terms of heat islands, flooding, poor air quality and the psychological effects of "hard" environments may be substantial yet wholly externalised.

The analysis was then mapped against beneficiaries and stakeholders these were spatially and functionally grouped. 


\section{RESULTS}

Using the ecosystem services framework as described above enabled stratification of the range of potential benefits and disbenefits from the greening for Melbourne's laneways. By taking a fully systemic approach, both recognised outcomes as well as some that may not previously have been recognised can be addressed.

\subsection{Identifying ecosystem benefits}

Potential benefits are summarised in Table 3, along with description of benefits recognised as significant.

Table 3: Ecosystems services provided by laneways.

\begin{tabular}{|c|c|c|}
\hline $\begin{array}{l}\text { Provisioning } \\
\text { services }\end{array}$ & $\begin{array}{l}\text { Description of potential provisioning service } \\
\text { benefit(s) }\end{array}$ & Beneficiaries \\
\hline Fresh water & $\begin{array}{l}\text { Contribution to the overall water cycle, with } \\
\text { marginal impact on water security for the city }\end{array}$ & $\begin{array}{l}\text { City residents, marginally } \\
\text { benefitting from water } \\
\text { supply }\end{array}$ \\
\hline Food & Benefit if planting contains some edible crops & Local people \\
\hline Fibre and fuel & $\begin{array}{l}\text { Small resource value if useful fibre plants } \\
\text { (kapok, etc.) are included in plantings }\end{array}$ & Local beneficiaries \\
\hline Genetic resources & $\begin{array}{l}\text { A genetic resource conservation role could be } \\
\text { served if local and scarce genetic strains form } \\
\text { the basis for plantings }\end{array}$ & $\begin{array}{l}\text { Multiple beneficiaries } \\
\text { including future } \\
\text { generations }\end{array}$ \\
\hline $\begin{array}{l}\text { Biochemicals, } \\
\text { natural medicines, } \\
\text { pharmaceuticals }\end{array}$ & $\begin{array}{l}\text { A resource conservation role could be served } \\
\text { if local and scarce strains of biochemical/ } \\
\text { medicinal value form the basis for plantings }\end{array}$ & Mainly local beneficiaries \\
\hline $\begin{array}{l}\text { Ornamental } \\
\text { resources }\end{array}$ & $\begin{array}{l}\text { Small Resource value if ornamental species } \\
\text { are included in plantings }\end{array}$ & $\begin{array}{l}\text { Local beneficiaries and } \\
\text { visitors }\end{array}$ \\
\hline Energy harvesting & No benefits perceived from greening & \\
\hline Regulating services & $\begin{array}{l}\text { Description of potential regulating service } \\
\text { benefit(s) }\end{array}$ & Beneficiaries \\
\hline $\begin{array}{l}\text { Air quality } \\
\text { regulation }\end{array}$ & Filtering dust and pollution from the air & $\begin{array}{l}\text { Public health, and } \\
\text { regulators/other with } \\
\text { public health interests }\end{array}$ \\
\hline $\begin{array}{l}\text { Microclimate } \\
\text { regulation }\end{array}$ & $\begin{array}{l}\text { Insulating buildings from heat and cold, } \\
\text { reducing energy expenditure and carbon } \\
\text { emissions } \\
\text { Reducing the Urban Heat Island (UHI) effect } \\
\text { through shading and cooling } \\
\text { Insulating the building in winter and summer, } \\
\text { reducing heating and cooling costs }\end{array}$ & $\begin{array}{l}\text { Owners and developers of } \\
\text { buildings benefitting from } \\
\text { improved indoor and } \\
\text { outdoor climate } \\
\text { regulation (health, energy } \\
\text { costs, overcoming "sick } \\
\text { building" syndrome, } \\
\text { knock-on for real estate } \\
\text { values, etc. }\end{array}$ \\
\hline $\begin{array}{l}\text { Global climate } \\
\text { regulation }\end{array}$ & $\begin{array}{l}\text { Averting the need for cooling/heating has } \\
\text { implications for climate-active gas emissions }\end{array}$ & $\begin{array}{l}\text { The international } \\
\text { community including } \\
\text { future generations }\end{array}$ \\
\hline Water regulation & $\begin{array}{l}\text { Diverting storm water run-off from laneways } \\
\text { into the soil } \\
\text { Reduced generation of storm flooding, } \\
\text { regulating flood risk on site and downstream } \\
\text { Recharging groundwater, helping buffer } \\
\text { potential drought impacts }\end{array}$ & $\begin{array}{l}\text { Beneficiaries of regulated } \\
\text { flood and drought risk at } \\
\text { catchment scale }\end{array}$ \\
\hline
\end{tabular}


Table 3: Continued.

\begin{tabular}{|c|c|c|}
\hline Regulating services & $\begin{array}{l}\text { Description of potential regulating service } \\
\text { benefit(s) }\end{array}$ & Beneficiaries \\
\hline $\begin{array}{l}\text { Natural hazard } \\
\text { regulation }\end{array}$ & $\begin{array}{l}\text { Minor effect on slowing air speeds (which } \\
\text { may or may not be an issue in enclosed } \\
\text { laneways) }\end{array}$ & Local people \\
\hline Pest regulation & $\begin{array}{l}\text { Hosting of pest predators (wasps eating } \\
\text { aphids, etc.) } \\
\text { Hosting some pests (flies, wasps, aphids, etc.) } \\
\text { necessitating careful management }\end{array}$ & Local people \\
\hline $\begin{array}{l}\text { Disease regulation } \\
\text { (human) }\end{array}$ & $\begin{array}{l}\text { Some benefit from air quality improvement } \\
\text { Potentially also from attenuating airborne } \\
\text { transmission of microbes (though this needs } \\
\text { further testing and verification) }\end{array}$ & Local and visiting people \\
\hline $\begin{array}{l}\text { Disease regulation } \\
\text { (stock) }\end{array}$ & None: no stock in the laneways & \\
\hline Erosion regulation & None: no erosion in the laneways & \\
\hline $\begin{array}{l}\text { Water purification } \\
\text { and waste treatment }\end{array}$ & $\begin{array}{l}\text { Minor impact possible, but considered trivial } \\
\text { relative to hydrological benefits }\end{array}$ & \\
\hline Pollination & $\begin{array}{l}\text { Benefit when pollinating species are hosted in } \\
\text { "green roofs", etc. }\end{array}$ & $\begin{array}{l}\text { Local people, including } \\
\text { adjacent urban gardens }\end{array}$ \\
\hline Salinity regulation & Not a perceived problem & \\
\hline Fire regulation & $\begin{array}{l}\text { A risk if combustible vegetation is } \\
\text { unmanaged and allowed to dry, necessitating } \\
\text { careful species selection and management }\end{array}$ & Local people \\
\hline $\begin{array}{l}\text { Noise and visual } \\
\text { buffering }\end{array}$ & $\begin{array}{l}\text { Reducing noise levels in the city } \\
\text { Providing some visual screening }\end{array}$ & $\begin{array}{l}\text { Local people, visitor } \\
\text { enjoyment and real estate } \\
\text { values }\end{array}$ \\
\hline Cultural services & $\begin{array}{l}\text { Description of potential cultural service } \\
\text { benefit(s) }\end{array}$ & Beneficiaries \\
\hline Cultural heritage & $\begin{array}{l}\text { Inclusion of characteristic local species can } \\
\text { imbue a local character to the laneways }\end{array}$ & Local people and visitors \\
\hline $\begin{array}{l}\text { Recreation and } \\
\text { tourism }\end{array}$ & $\begin{array}{l}\text { Can turn the laneways into an even more } \\
\text { attractive tourism attraction and recreational } \\
\text { space }\end{array}$ & $\begin{array}{l}\text { Local people, visitors, } \\
\text { local businesses and } \\
\text { tourism interests }\end{array}$ \\
\hline Aesthetic value & $\begin{array}{l}\text { Provision of useable green outdoor space for } \\
\text { businesses in laneways e.g. bars, cafes and } \\
\text { restaurants } \\
\text { Provision of more green public open spaces } \\
\text { in the central city }\end{array}$ & $\begin{array}{l}\text { Local people, visitors, } \\
\text { local businesses and } \\
\text { tourism interest }\end{array}$ \\
\hline $\begin{array}{l}\text { Spiritual and } \\
\text { religious value }\end{array}$ & $\begin{array}{l}\text { None perceived that is not addressed by } \\
\text { "cultural" and "aesthetic" considerations } \\
\text { above }\end{array}$ & \\
\hline $\begin{array}{l}\text { Inspiration of art, } \\
\text { folklore, } \\
\text { architecture, etc. }\end{array}$ & $\begin{array}{l}\text { Local species and a greener environment can } \\
\text { deepen the value of the laneways as a centre } \\
\text { for the arts, as well as accentuating the } \\
\text { distinctiveness of laneway architecture }\end{array}$ & $\begin{array}{l}\text { Local arts and crafts } \\
\text { interests, local businesses }\end{array}$ \\
\hline
\end{tabular}


Table 3: Continued.

\begin{tabular}{|c|c|c|}
\hline Cultural services & $\begin{array}{l}\text { Description of potential cultural service } \\
\text { benefit(s) }\end{array}$ & Beneficiaries \\
\hline Social relations & $\begin{array}{l}\text { Increasing surrounding property values } \\
\text { Reinvigorating laneways from waste areas to } \\
\text { useable public spaces } \\
\text { Provision of more pleasant walkways and } \\
\text { thoroughfares, encouraging people to walk } \\
\text { and spend time outdoors } \\
\text { Reducing vandalism and antisocial behaviour } \\
\text { Building local people engaging and } \\
\text { collaborating around improving the } \\
\text { environment of their shared spaces }\end{array}$ & $\begin{array}{l}\text { Local communities, with } \\
\text { potential direct local } \\
\text { business and tourism } \\
\text { "knock on" benefits }\end{array}$ \\
\hline $\begin{array}{l}\text { Educational and } \\
\text { research }\end{array}$ & $\begin{array}{l}\text { Creates "indoor green classrooms" as well as } \\
\text { research opportunities }\end{array}$ & $\begin{array}{l}\text { Local schools and } \\
\text { universities }\end{array}$ \\
\hline Supporting services & $\begin{array}{l}\text { Description of potential supporting service } \\
\text { benefit(s) }\end{array}$ & Beneficiaries \\
\hline Soil formation & Benefit unlikely in this setting & \\
\hline Primary production & $\begin{array}{l}\text { Small amount of biomass production } \\
\text { Potential disbenefit of fall of dead leaves } \\
\text { requiring removal }\end{array}$ & $\begin{array}{l}\text { Indirect benefits to } \\
\text { biodiversity } \\
\text { Local authorities }\end{array}$ \\
\hline Nutrient cycling & Small/minimal benefit in this setting & \\
\hline Water recycling & $\begin{array}{l}\text { Localized evaporation and recapture by } \\
\text { vegetation, can contribute to a cooler } \\
\text { microclimate and other beneficial services }\end{array}$ & Local traders and tourists \\
\hline $\begin{array}{l}\text { Photosynthesis } \\
\text { (enhanced } \mathrm{O}_{2} \text { ) }\end{array}$ & Small/minimal benefit in this setting & \\
\hline Provision of habitat & $\begin{array}{l}\text { Selection of appropriate vegetation enhances } \\
\text { biodiversity, contributes to genetic diversity } \\
\text { and, potentially, wider nature conservation } \\
\text { goals }\end{array}$ & Local traders and tourists \\
\hline
\end{tabular}

A significant body of ecosystem services science recognises that benefit realisation from ecosystem services can span a range of scales [21]-[23]. The section below maps some of these benefits spatially.

\subsection{Mapping benefits to stakeholders}

Understanding of the stakeholders benefitting from greening was derived from the ecosystem services analysis in section 3.1. These have been grouped by spatial scale and the benefit classes depicted in relation to these spatial groups on Fig. 1. It shows that many of the identified benefits are concentrated at a very local scale. This is related to the relatively smallscale adaptation of individual laneways. Larger spatial-scale benefits identified relate to genetic resources and climate regulation. These benefits may be felt at global, national and regional scale but the marginal contribution of the laneways to macro-climate cannot be seen as critical, and a contribution to genetic resources would require very careful design and planning. City-scale benefits are related to regulation of water and natural hazards. Local residents and businesses may also derive indirect benefit from these large spatial scale impacts through feedback mechanisms of tourism (if sufficiently publicised), improved property value and reduced local taxes. This analysis therefore suggests that the majority of 


\section{Mapping of potential benefits from greening of laneways}

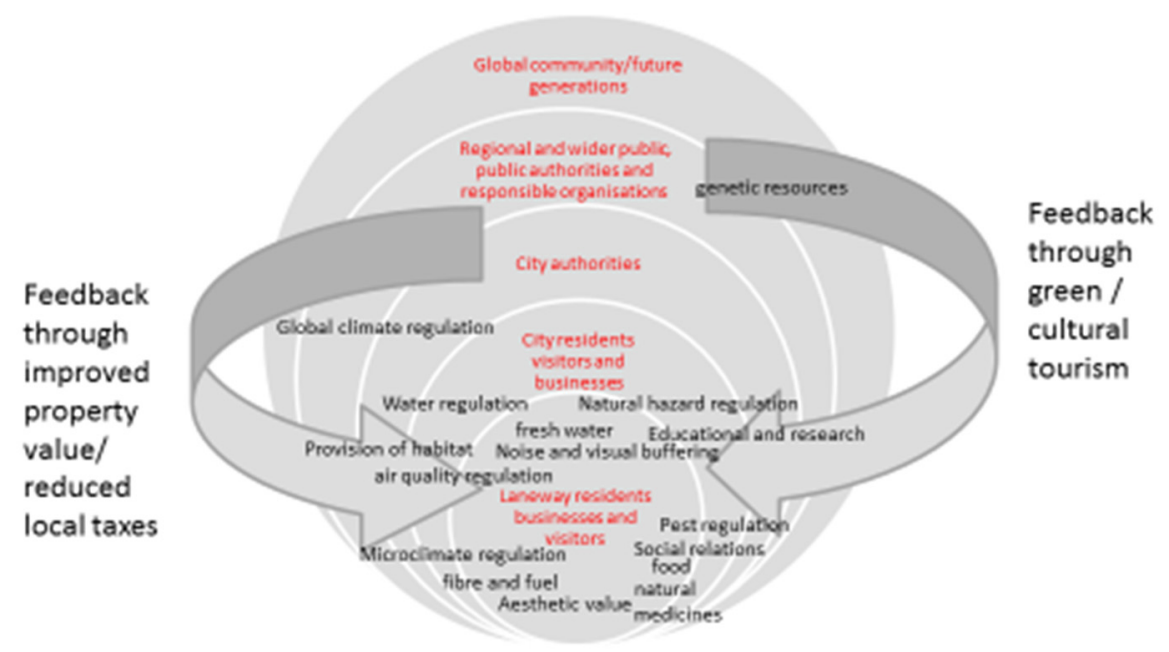

Figure 1: Distribution of benefits of greening laneways across spatial scales including feedbacks.

the funding for laneways would sensibly be asked from local beneficiaries with some national and regional support for environmental benefits such as biodiversity protection or enhancement.

The focus on local residents and businesses as well as the potential to enhance the benefits through a focus on green and cultural tourism opens up the possibility to offer city-wide businesses and residents a chance to invest in the projects through crowd funding. Their willingness to donate will be linked to their perception of the proposed laneways, and participation in and ownership of the laneways concept and design.

\section{DISCUSSION}

In most operational contexts, a central driving disciplinary need or policy imperative tends to drive natural resource use or management decisions. The driving factor may dominate decision-making with respect to use of the resource, overlooking or dismissing other linked services. This was not the case for the laneways project, enabling a broad-ranging exploration of benefits before and during implementation, considering a broad spectrum of potential benefits and disbenefits including many commonly unaccounted or disregarded externalities. Increasing selected ecosystem services is of prime importance and generates specific societal value, but there is a risk that lack of attention to non-focal ecosystems may cause detriment that can diminish overall societal benefit. Analysis of change should be couched within an understanding of the totality of the ecosystem services provided by a habitat or ecosystem. Considering other systemic impacts, means that focal services can form an "anchor" around which other linked ecosystem service outcomes can be considered and optimised [24]. This study was limited to consideration of the introduction of new ecosystem services, other local partners in this project observing that extant ecosystems in the laneways pre-greening are 
minimal. Recognition that management and policy initiatives present systemic options is an important step towards increasingly systemic practice.

As both natural and managed ecosystems generate linked sets of services that cumulatively provide greater societal benefit than the sum of individual services [25], a systemic overview of outcomes from different management options is important if we are to avoid the myopia for considering single ecosystem services in isolation. These sets of linked "environmental services" have also been described as "bundles", comprising "...sets of different services that interact synergistically and occur simultaneously across landscapes provided by different land uses" [26]. Whilst not all individual aspects of ecosystem use can be fully accounted for, when considered as a system the cumulative value of multiple marketed and non-marketed services can be seen to be substantial. For example, an overall ecosystem service value for global forests has been calculated at over $\$ 16$ trillion [27], of which only $6 \%$ of temperate forest and $1.6 \%$ of tropical forest valuation is from the bundled provisioning service of "raw materials" [28]. Recognition of this multiplicity of linked benefits, or the potential for the erosion of societal value where non-focal services are overlooked and commonly inadvertently degraded, is important for engaging all interests in society in collectively beneficial interventions. Systemic consideration of ecosystem services also has significant implications for social justice and net societal value [23].

In that context, systemic solutions contribute to sustainable development by allowing for a wider optimisation of benefits and the avoidance of unintended negative impacts. Ideally, this is carried out in conjunction with the evaluation of other planned or potential adjacent ecosystems service enhancements. The greening of laneways, could be considered alongside a converging range of ecosystem-based urban management technologies (including for example SuDS, or sustainable drainage systems), wetlands, and washlands, and rehabilitation of urban rivers. Further research is needed to optimise approaches across systems from the urban and into the peri-urban and to constitute systemic solutions that optimise benefits across a linked set of ecosystem services [11].

In the context of urban design, the importance of often neglected urban ecosystems and their processes are recognised as of vital importance to the viability of cities, just as resource flows supporting urban life reach out into rural and increasingly global hinterlands [20]. This point highlights the importance of recognition and internalisation of these ecosystem services into decision-making for sustainable built environments. The natural infrastructure of cities includes a complex mosaic of often overlooked ecosystem services. These include: flow paths and infiltration opportunities formed by the existing topography; drainage systems and permeability of the landscape that aid stormwater management; noise and visual mitigation through GI such as street trees and green spaces; aesthetic enhancement and amenities from BGI; and cooling through shading and evapo-transpiration to reduce urban heat. These types of beneficial habitats and processes can be emulated in microcosm through greening laneways, with a range of linked ecosystem service co-benefits. Municipal government has a lead role to play in brokering dialogue about recognition, realisation and optimisation of multiple benefits in many aspects of urban planning, design and management, the crucial factor being how it develops and appraises options in the planning process, and how it engages with multiple stakeholders comprising potential linked beneficiaries of ecosystem services.

\section{CONCLUSION}

Our analysis based on the ecosystem services framework broadened the range of benefits explored relative to traditional approaches more narrowly focused on single outcomes. In particular, it identified the potential to optimise overall benefits in the delivery of urban 
greening. For example, the inclusion of rare or iconic native species adapted to conditions occurring in the laneways, potentially including those with pharmaceutical properties, could create educational and other a national or regional interest in the programme, broadening its appeal and potentially attracting new sources of funding. Creative thinking about native plantings may in turn attract other native and potentially rare wildlife, creating an urban ecological haven of broad ecological, social and economic value.

We propose that by widening the consideration of benefits, using the systemic ecosystem service framework to extensively consider potential benefits and disbenefits, before and during project design phases can be very useful in order to: widen participation; tailor design to optimise benefits; provide a coherent model facilitating pooling of often fragmented outcome-specific budgets; attract novel funding from special interest groups; and increase visibility and potential for improved feedback benefits such as green tourism and property value.

All of these benefits are, in reality, intimately interconnected and must therefore be planned on an integrated basis if unintended negative consequences are to be averted and synergies are to be achieved. Mapping of the benefits on a spatial scale provides a basis for a coherent communication plan, including potential co-funding partners in the design and recognising the benefits of a collaborative approach.

\section{ACKNOWLEDGEMENTS}

The authors acknowledge funding from NERC NE/N019180/1 and the EPSRC EP/P004237/1 as well as the collaboration of Melbourne City Council, Newcastle University, David Hetherington of ARUP and Thick Media in formative discussions.

\section{REFERENCES}

[1] Lindt, R., The Avalon Green Alley Network Demonstration Project: Lessons Learned From Previous Projects for Green Alley development in Los Angeles \& Beyond, UCLA Luskin Center for Innovation, 2015.

[2] Dillon, M., Little streets in small cities: The role of laneway activation in regional queensland cbd revitalisation. Faculty of Health, Engineering \& Sciences, University of Southern Queensland, 2013.

[3] Martin, M.D., The question of alleys, revisited. URBAN DESIGN International, 6(7692), 2001.

[4] Newell, J.P. et al., Green alley programs: Planning for a sustainable urban infrastructure? Cities, 31, pp. 144-155, 2013.

[5] Grant, G., Ecosystem Services Come To Town: Greening Cities by Working With Nature, Wiley-Blackwell: Chichester, 2012.

[6] Everett, G. \& Lamond, J., Perceptions of green roofs in UK commercial real-estate. Journal of Corporate Real Estate, 21(2), pp. 147-164, 2019.

[7] Lamond, J.E., Wilkinson, S. \& Rose, C., Conceptualising the benefits of green roof technology for commercial real estate owners and occupiers. Resilient Communities, Providing for the Future, 20th Annual Pacific Rim Real Estate Conference, PRRES: Christchurch, 2014.

[8] Everard, M., The Ecosystems Revolution: Co-creating a Symbiotic Future, PIVOT Series, Palgrave, 2016.

[9] Johnson, T., Treenet Trials 2009: A Species Odyssey, Mitcham, 2009.

[10] Hoyle, H., Hitchmough, J. \& Jorgensen, A., All about the 'wow factor'? The relationships between aesthetics, restorative effect and perceived biodiversity in designed urban planting. Landscape and Urban Planning, 164, pp. 109-123, 2017. 
[11] Civil Exchange, Whose Society? The Final Big Society Audit, Civil Exchange, 2015.

[12] Tourism Australia, Melbourne's hidden laneways, 2016. www.australia.com/en/ places/vic/melbourne-hidden-laneways.html.

[13] City of Melbourne, Greening laneways, 2020. www.melbourne.vic.gov.au/ community/greening-the-city/green-infrastructure/Pages/greening-laneways.aspx. Accessed on: 9 Mar. 2020.

[14] City of Melbourne, Benefits of green laneways, 2016. www.melbourne.vic.gov.au/ community/greening-the-city/green-infrastructure/pages/greening-laneways.aspx. Accessed on: 3 May 2020.

[15] World Resources Institute, Ecosystems and Human Well-Being: A Framework For Assessment, Island Press, 2003.

[16] Dugan, P.J., Wetland Conservation: A Review of Current Issues and Required Actions, Gland: IUCN (World Conservation Union), 1990.

[17] Everard, M., Denny, P. \& Croucher, C., SWAMP: A knowledge-based system for the dissemination of sustainable development expertise to the developing world. Aquatic Conservation, 5(4), pp. 261-275, 1995.

[18] TEEB, The Economics of ecosystems and biodiversity: mainstreaming the economics of nature: A synthesis of the approach, conclusions and recommendations of TEEB, in the economics of ecosystems and biodiversity, 2010. http://doc.teebweb.org/wpcontent/uploads/Study\%20and\%20Reports/Reports/Synthesis\%20report/ TEEB\%20Synthesis\%20Report\%202010.pdf.

[19] CICES, Welcome to the CICES website, 2016. http://cices.eu/.

[20] UK NEA 2010, UK National Ecosystem Assessment. http://uknea.unep-wcmc.org/.

[21] Fisher, B. \& Turner, R.K., Ecosystem services: Classification for valuation. Biological Conservation, 141, pp. 1167-1169, 2008.

[22] Turner, R.K., Georgiou, S. \& Fisher, B., Valuing Ecosystem Services: The Case of Multifunctional Wetlands, Earthscan Publishing: London, 2008.

[23] Everard, M., Ecosystems Services: Key Issues, Routledge, 2017.

[24] Everard, M., Nature's marketplace. The Environmentalist, pp. 21-23, Mar. 2014.

[25] Schomers, S. \& Matzdorf, B., Payments for ecosystem services: A review and comparison of developing and industrialized countries. Ecosystem Services, 6, pp. 1630, 2013.

[26] Balvanera, P. et al., The links between biodiversity and ecosystem services. Routledge Handbook of Ecosystem Services, eds M. Potschin, R. Haines-Young, R. Fish \& R.K. Turner, Routledge: London, pp. 45-61, 2016.

[27] Costanza, R. et al., Changes in the global value of ecosystem services. Global Environmental Change, 26, pp. 152-158, 2014.

[28] de Groot, R. et al., Global estimates of the value of ecosystems and their services in monetary terms. Ecosystem Services, 1, pp. 50-61, 2012. 